\title{
On the Informational Role of Delayed Good News: A Firm-Level Crash Risk Evidence from Egypt
}

\author{
Abd El-Rahman M. Selmy ${ }^{1} \&$ Khairy A. El-Giziry ${ }^{2}$ \\ ${ }^{1}$ Faculty of commerce, Portsaid University, Egypt, ${ }^{2}$ Faculty of commerce, Cairo University, Egypt \\ Correspondence: Abd El-Rahman M. Selmy, Faculty of commerce, Portsaid University, Egypt, ${ }^{2}$ Faculty of \\ commerce, Cairo University, Egypt
}

Received: May 9, 2016

Accepted: June 25, 2016

Online Published: June 30, 2016

doi:10.5430/afr.v5n3p44

URL: http://dx.doi.org/10.5430/afr.v5n3p44

\begin{abstract}
There is controversy regarding the impact of delayed good news and information asymmetry in financial reporting on firm-level crash risk. In the current exposure draft on the conceptual framework of financial reporting, information asymmetry is not considered a desired characteristic. We presented a framework for the demand for conservatism to mitigate information asymmetry and thus, decreasing the potential exposure to firm-level crash risk. Kim and Zhang (2010) claimed and provided evidence that conservatism is incrementally significant as a proxy of information asymmetry for predicting firm-level crash risk. If that claim is true, however, it will be sensible to argue that information asymmetry is non-trivial for firm-level crash risk assessment. Toward that end, this study directly tests if the timeliness of good news is trivial for firm-level crash risk assessment by specifying the firm-level crash risk in terms of a conservatism model. The study employed sample data from Egypt's capital market, which defines a setting dominated lately by firm-level crashes. We found evidence that timeliness of good news versus bad news explained by information asymmetry is significantly increasing the probabilities of experiencing firm-level crash risk; however, we found that conservatism reduces information asymmetry which eventually reduces the potential exposure to firm-level crash risk.
\end{abstract}

Keywords: Crash risk, Timeliness of news, Information asymmetry, Conservatism

\section{Introduction}

Crash risk is an economic and a psychological phenomenon and an important characteristic of return distribution that is relevant to portfolio theories, asset-pricing, and option-pricing models. Stock-price crash risk is defined as experiencing frequent negative skewness in stock returns that is asymmetrically distributed and described simply by unexpected large movements in the stock returns that are usually decreasing, rather than increasing. This is reflected in stocks being traded far above their intrinsic value creating an economic bubble that keeps the desire of investors as for investment in firms being questioned. Roots for stock-price crash attained arousing attentions especially since the tremendous 2008 financial crisis. Since that dramatic market-wide price declines, stock-price crash risk has undergone lots of research aiming for better predictability and handling in order to lessen its adversity. Stock market returns are among the most important indicators of financial performance (Ansari \& Riasi, 2016; Riasi \& Pourmiri, 2015); therefore a stock price crash can have a severe negative impact on a firm's financial stability and competitiveness (Riasi, 2015; Riasi \& Amiri Aghdaie, 2013).

Information asymmetry is one of the main drivers behind negative skewness in stock price returns that broadly implicated two aspects: (1) hidden information shown in adverse selection problem (Akerlov, 1970), and (2) hidden action (agency problem) shown in moral hazard problem (Jensen \& Meckling, 1976). We considered two major components behind information asymmetry; the management of the company due to selfish motives does something towards apparently increasing the current performance of the company (i.e., continuing projects with negative present value, lack of transparency of financial information, tax evasion, etc.) and the behavior of the firm's management concerning the timelier recognition of losses versus gains.

Financial economists have always viewed stock price changes as tied to firm-specific information. Managers' asymmetric disclosure incentives imply that there is more privately received bad news than good news remaining to be disclosed at the end of the period - which is behind the investors' timely quest for more information in both quantity and quality aspects (i.e., market transparency) - hoping that poor current performance will be camouflaged 
by strong future performance and that the firm's situation improves before the required information is released. If managers keep withholding and accumulating bad news for an extended period, negative information is likely to be stockpiled and becomes too costly to continue withholding it, leading to a large, negative, and an abrupt decline in stock price.

Morck, Yeun, and Yu (2000) showed that the explanatory power of a market model (i.e., the complement of firm-specific return variation) is lower (higher) with greater (less) information asymmetry. However, in a model of incomplete revelation (i.e., incomplete transparency) of firm-specific news, crash risk models, such as that of Jin and Myers (2006), are built on the concept of bad news hoarding behavior and/or recognizing unverifiable good news. One can argue, however, that outside investors can gain access to adverse private information in a timely manner via private information search activities which will reduce the likelihood of future crashes for non-conservative firms. In other words, to the extent that private information search is not prohibitively costly, it can substitute for conservatism. In such case, there would be little difference in future crash likelihoods between conservative and non-conservative firms. However, Aboody and Lev (2000), among others, argued that private information search is costly and optimal information acquisition by outsiders generally does not exhaust a manager's private information.

Assessment-wise, however, though the complement of the firm-specific return variation speaks, by definition, for the second moment of the return distribution, the firm-level crash risk assessed in terms of a large, negative skewness in returns defines the third moment of that distribution. In this concern, Kim and Zhang (2010) documented that the conservatism's ability to predict firm-level crashes is incrementally significant. Adhering to this logic and in conjunction with assuming the truth of Kim and Zhang's evidence, conservative timeliness of good news is predicted to explain the contemporaneous variation underlying assessed firm-level crashes.

Thus, in an environment of high information asymmetry, this study directly tests if the timeliness of good news explained via information asymmetry is trivial for firm-level crash risk assessment by specifying the firm-level crash risk in terms of a conservatism model.

This paper is structured as follows: The next section provides the relevant literature and the development of the study hypotheses. Section three describes data and research design. Section four presents the empirical results and analysis. Finally, in section five, conclusions, limitations, and directions for future research are put forth.

\section{Literature Review and Hypothesis Development}

The managerial tendency to conceal bad news from outside investors engenders crash risk, or, more generally, negative return skewness in stock returns (McNichols, 1989). This is because the asymmetric disclosure behavior of managers leads to stockpiling negative information unknown to outside investors. When the accumulated bad news reaches a certain tipping point and the managerial incentive for hiding bad news collapses, the large amount of negative information will suddenly and immediately be released to the market, leading to a sudden decline in stock price or a crash. Basu (1997) estimated reverse regressions of annual earnings on contemporaneous returns using positive (negative) annual stock returns as a proxy for good (bad) news. The R2 (i.e., the contemporaneous sensitivity of earnings) is found to be higher for firms with negative stock returns than for firms with positive returns. Chen, Hong, and Stein (1999) investigated the determinants of asymmetries in stock returns and found that negative asymmetries are more likely to occur when there are large prevailing differences of opinions among investors. Basu, Hwang, and Jan (2001) examined the asymmetric timeliness of quarterly earnings in reporting news as a measure of conservatism and showed that quarterly earnings are more-timely in reporting bad news than good news. Consequently, Watts (2003a) explained that the need for conservatism originated from the existence of (1) information asymmetries; (2) asymmetries in compensation contracts; (3) limited liability; and (4) the fact that the parties to the firm have different time-horizons. Kirschenheiter and Melumad (2005) stated that managers employ discretion in reporting to increase the quality of earnings reported and that the manager's disclosure strategy depends on whether he observes good or bad news. Moreover, DeFond, Hung, and Trezevant (2005) found that annual earnings announcements are more informative in countries with higher quality earnings or better enforced insider trading laws and less informative in countries with more frequent interim financial reporting. Huang and Zhou (2006) assumed that delaying the reporting lag is motivated by managers' attempts to influence the shareholders' valuation or perception of the firm's value and found that firms with good news tend to make an early announcement unlike firms with bad news. Guay and Verrecchia (2006) argued that conservatism can be interpreted as more timely recognition of losses than gains resulting from asymmetric costs and benefits of reporting verifiable information by managers with incentives to distort firm performance and emphasized conventions that report bad news in a timely manner but good news in an untimely manner creates informational inefficiencies. 
Jin and Myers (2006) extended the work of Myers (2000) and investigated the relationship between the lack of informational transparency and stock price crash. Depending on O'Hara's (2003), they assumed that all outside investors are imperfectly informed and all private information is held by inside managers. They found that when the accumulated hidden bad news comes out, extreme negative outcomes in stock returns took place (i.e., stock price crash) and that less transparent markets exhibit more frequent crashes. Bleck and Liu (2007) proclaimed that the hiding of bad news hinders outside investors from abandoning bad projects at an early stage and thus, firms with aggressive reporting approach are more likely to keep bad projects for a longer period, compared with firms with conservative reporting approach. $\mathrm{Li}$ (2007) documented that managers of more conservative firms tend to make more voluntary disclosures in the form of earnings guidance and noted that both conservatism and management forecasts are part of a firm's long-term disclosure policy. Shroff, Venkataraman, and Zhang (2007), and Roychowdhury and Sletten (2008) examined the asymmetric timeliness and stated that information is incorporated in earnings earlier if it reflects good news than if it reflects bad news. They found that managers tend to pre-announce good news although earnings are not yet delivered and moreover, not all news events that arrive are announced by managers. LaFond and Watts (2008) focused on equity market demand for conservatism and argued that information asymmetries between corporate insiders and outside equity investors recommend engendering conservatism in financial reporting. This is because conservatism reduces information asymmetry by curbing managers' incentives, opportunities, and ability to overstate income and net asset values.

On one hand, Yifang Wan (2009) proved that firms with stronger corporate governance would be more likely to voluntarily disclose corporate information using public rather than selective methods and that this would be associated with lower levels of information asymmetry, but on the other hand, Kothari, Shu, and Wysocki (2009), and Claudia Z. Qi (2011) stated that managers have incentives to voluntarily disclose good news early and delay bad news disclosure and provided evidence that earnings assume a proportionately greater role in disclosing bad news when the firm's unverifiable growth options and/or poorer information environments generate greater information asymmetry between managers and shareholders (adverse selection problem). Hutton, Marcus, and Tehranian (2009), and Zhao and Chen (2011) considered the empirical link between information opacity, information risk, and stock-price crash risk. They proved that information asymmetry has the explanatory power of stock price crash risk and positively associated future stock price crash risk to the opaqueness of financial reporting consistent with Jin and Myers (2006). Kim and Zhang (2010) and Moradzadehfard, Lotfi and Fathi (2011) indicated that greater extent of conservatism in financial reporting significantly reduces the likelihood of firms to experience future stock price crashes which provide evidence that the predictive power of conservatism with respect to future crash risk is stronger in an environment where investors are faced with larger information asymmetries. Andrew Van Buskirk (2011) showed that firms with greater volatility skew are more likely to experience large earnings period stock price drops declaring that having information about future earnings is not the same as knowing them when they are revealed due to non-timely disclosure of information. Allam, Mohammed, and Mahmud (2011) showed that the public sector of regulating reporting standards succeeded in forcing Kuwait companies to present a reasonable level of conservatism and found that the financial statements of small companies were conservative, while those of the big ones were not and that companies with lower debts were more conservative than those of higher ones.

Ahmed and Duellman (2011) proved that if conservatism reduces managers' incentives to hide bad news, this will in turn act for increasing the profitability of the firm. Chan, Jiang, Xu, and Yi (2012) found that conflicts of interests can bias the analyst coverage letting managers hold negative information resulting in future stock price crash risk. Hamm, Li, and Ng (2012) extended the work of Hutton, Marcus, and Tehranian (2009) and found that managers that provide more earnings guidance tend to provide more over-optimistic guidance, and thus are more likely to experience a future stock price crash risk, which contrasted the general notion that more guidance would enhance transparency and reduce crash risk. Kim, Yeung, and Zhou (2013) extended the undertaken research on firm-level determinants of stock price crashes done by Jin and Myers (2006), Hutton, Marcus and Tehranian (2009), and Kim and Zhang (2012). They proved that Firms with internal control weakness problems tend to facilitate managers' bad news hoarding behavior, and therefore, are more prone to experience stock price crashes relative to firms with no such problem. Kim, $\mathrm{Li}$, and $\mathrm{Li}$ (2014) found a significant negative association between firms' CSR performance and stock price crash risk revealing that if socially responsible firms commit to a high standard of transparency and engage in less bad news hoarding, they would have lower crash risk. Biddle, Ma, and Song (2012), Mohammadi and Salehirad (2012), and Dimitrios V. Kousenidisa, Anestis C. Ladasb, and Christos I. Negakis (2014) examined conservatism's informational properties and the impact of conservatism that has been found to improve financial reporting efficiency on the prediction of stock price crash risk. 
In light of the lack of previous studies of timeliness of financial reporting practices by firms in the Egyptian capital market and to supplement the academia discussed above, this study attempted to Understand and document firm-specific drivers behind firm-level crashes and identify the informational impact of timeliness of good news on its potentiality which is met by empirically testifying the relationship between firm-level crash risk and the delayed good news (i.e., timeliness of good news) measured as the extent information asymmetry in financial reporting and proxied via conservatism.

To uncover systematic evidence for the above argument and aiming to investigate the impact of delaying good news on firm-level crash risk potentiality, we tested the following alternate hypothesis:

\section{H1: delayed good news is positively related with the occurrence of firm-level crash risk}

We aimed to emphasize the importance of adopting the asymmetric verifiability version of conservatism, which includes both the concept of timely loss recognition and the postponement of good news recognition until the profit is verifiable ( i.e., a high degree of verification before making a legal claim to any profit). From this point, we drew our second hypothesis which is:

\section{H2: conservatism in financial reporting reduces information asymmetry}

Watts (2003a) explained that, from a contracting and litigation risk point of view, conservatism originates from the existence of information asymmetry. Thus, in an environment of high information asymmetry, our second hypothesis is based on the notion that conservatism works on limiting the managers' ability to withhold and accumulate adverse private information from outside investors, which, in turn, leads to lowering future crash likelihood for conservative firms.

\section{Research Methodology}

This study defined a quantitative research that strictly adheres to the traditional, scientific paradigm where a parsimonious specification is estimated via employing a sample data from Egypt. The specification, in this fashion, explains the firm-level crash risk in terms of [1] less revelation of firm-specific news (i.e., the information asymmetry component) and [2] delayed recognition of good news (i.e., the governance disciplining reporting mechanism component of conservatism). The objective is to test whether the conservatism's ability to predict firm-level crashes is incrementally significant via [1] empirically assessing the explanatory power of a Logit, maximum likelihood model, and [2] testing hypotheses replicating research tenor.

\subsection{Sample and Data Collection}

Our sample is drawn from the intersection of data from the Egyptian Capital Authority Market, Egypt for Information Dissemination Co., and online sources based on market capitalization EGY X30 for the period 2009-2013. Consecutively, we imposed the following selection criteria: First, similar to Khan and Watts (2009), we required that total assets and book values of equity for each firm be greater than zero. Second, to be included in the sample, a firm must have at least 50 weekly returns for each fiscal year. Third, following Khan and Watts (2009), we excluded firms in each sample year that fall in the top and bottom percentiles of earnings, annual returns, and market value of equity, market-to-book ratio, or leverage. Lastly, we deleted firm-years with missing data for the research variables used in our regression. After applying prior sample-size determination criteria, the final sample size is reduced to 22 Egyptian firms spanning all sectors of the Egyptian capital market.

\subsection{Research Model and Variables Measurement}

When returns fall outside of a normal distribution, the distribution exhibits skewness. Skewness is known as the third "moment" of a return distribution, with the mean and the variance being the first and second moments, respectively. Skewness measures the degree of asymmetry of a distribution around its mean. Following Chen et al. (2001) and Kim et al. (2010), our measure of crash likelihood is the negative conditional return skewness (NCSKEW) measure. Specifically, we calculated NCSKEW for a given firm quarterly instead of annual computation by taking the negative of the third moment of firm-specific weekly returns during the firm's quarterly observations for a specific fiscal year, and divided it by the standard deviation of firm-specific weekly instead of daily returns raised to the third power. Specifically, for each firm $j$ in year $t$, we obtain NCSKEW as:

$$
\operatorname{NCSKEW}_{j . t}=-\left.\left(n(n-1)^{3 / 2} \sum R_{j . t}^{3}\right)\right|_{\left((n-1)(n-2)\left(\sum R_{j . t}^{2}\right)^{3 / 2}\right)}
$$


Where $R_{j . t}$ represents the sequence of weekly returns to stock $j$ during period $t$ and $n$ is the number of observations on weekly returns during the period. These weekly returns are -more precisely- the log changes in price. This is simply the negative of the third standardized moment of weekly returns of firm $j$ over the one year period $(t-1, t)$ (i.e., the third moment in terms of the $z$-score raised to the power of three). Here, the estimates of the mean and variance are based on 50-52 weekly observations. NCS is thusE $\left[-\left(\frac{x-\mu}{\sigma}\right)^{3}\right]$.

We introduced this measure of crash risk as one may suspect that less conservative firms are, in general, related to longer tails; that is, they have not only more crashes but also more positive jumps. Therefore, the use of negative skewness as an alternative measure mitigates this concern. Scaling the third moment by the standard deviation cubed allows for comparisons across stocks with different variances; this is the usual normalization for skewness statistics (Greene, 1993). By putting a negative sign in front of the third moment, we are adopting the convention that an increase in NCSKEW corresponds to a stock being more "crash prone" - i.e., having a more left-skewed distribution.

Depending on FASB (1980), Gibbins (1980), Lee et al. (2008), and IASB (2010), information asymmetry is used as an explanatory variable for delayed good news (i.e., timeliness of good news). Since the study hypotheses is related to the ability of news-dependent to forecast the likelihood of future crash occurrence, we used degree of conservatism as a proxy for information asymmetry for each firm in each sample year and measured it using Basu measure - the parameter estimate of the firm-specific asymmetric earnings timeliness over the one year period $(\mathrm{t}-1, \mathrm{t})$, $\beta_{4}$, which was developed by Basu (1997). To test for asymmetric timeliness, we used positive and negative returns as proxies for good and bad news, and estimated a regression of earnings using closing stock price on current returns rather than opening stock price unlike Basu (1997), with intercept and slope dummies for negative returns. Basu (1997) estimated the following piecewise linear regression as:

$$
X_{j, t}=\beta_{1}+\beta_{2} D_{j, t}+\beta_{3} R_{j . t}+\beta_{4} D_{j . t} * R_{j . t}+\varepsilon_{j . t}
$$

Where $j$ indexes firm and $t$ indexes are used for quarter instead of annual observations used by Basu for each firm, $X$ is $N I_{j . t} / M V_{j . t}$ which is net income scaled by lagged market value of equity computed as earnings normalized by the market value of equity, $R$ is the compound returns over the 50-52 week instead of 12-month period formulated mathematically as $\ln \left[P_{t} / P_{t-1}\right], D$ is a dummy that takes one if the return is negative (i.e., $P_{t-1}>P_{t}$ ) and zero otherwise.

$\beta_{1}$ is an intercept term that describes the value of earnings when it is strictly zero. $\beta_{2}$ is meaningless and is considered the change in earnings with respect to an indicator function. $\beta_{3}$ is the change in earnings stimulated by a corresponding change in returns when the returns are positive. $\beta_{4}$ is the Basu coefficient that measures the incremental timeliness of earnings in recognizing bad news relative to good news which is a simple measure of how negative returns are replicated in earnings. Larger Basu coefficient indicates higher degree of conservatism.

The estimation of Basu (1997) coefficient requires the market to be efficient with respect to publicly available information. We assumed that for conservative firms the higher levels of monitoring and better governance reduce the amount of private information withheld by managers. This assumption, based on hidden private information, allows the use of the Basu model, since Basu does not require the market to be efficient with respect to private information (Kim and Zhang, 2010). The observed asymmetric timeliness implies the differential verification standards required for bad news recognition versus good news recognition by the firm's financial information reporting policy.

Accordingly, our explanation for the computations of both conservatism and crash risk is as follows: if a firm's Basu measure computation value has a negative sign this means that this company is aggressive referring to the tendency to reveal good news as early as possible but hiding or delaying the reveal of bad news that weakens the financial position or lead to a decrease (i.e., negative skewness) in stock price, (i.e., this company is entertaining higher degrees of information asymmetry) which if accumulated to a certain tipping point would lead to a certain 
stock-price crash risk. On the other hand, a positive value of Basu measure computation means that this company is conservative as it tends to reveal bad news as early as they are incurred as well as good news (i.e., this company is entertaining lower degrees of information asymmetry) which means that being conservative mitigates information asymmetry-sequentially negative skewness-and thus decreased probabilities of experiencing stock-price crash risk.

\section{Analysis and Discussion}

In this section, we identified the functional form of the specification in which we defined crash risk as a function of conservatism which means that the value of crash risk varies accordingly with the extent of conservatism firms entertain in their financial reporting mechanism. Crash risk $=\mathrm{f}($ conservatism $)$, Crash risk $=\mathrm{b} 0+\mathrm{b} 1 *$ conservatism + error.

If a firm's computational observations showed that the firm is conservative accompanied by a lower value for experiencing crash risk, then the hypotheses will be proved to be valid that conservatism has an informational role in mitigating information asymmetry and thus lowering the possibilities of experiencing firm-level crash risk. If the contrary occurred, then this means that conservatism has no informational role and no significant impact on firm-level crash risk. Thus, the regression model of this study involved the following variables: (1) the independent variables, $\mathrm{X}$, which is the delayed news (i.e. timeliness of news), and (2) the dependent variable, $Y$, which is the firm-level crash risk.

Table 1. presents the descriptive computations for conservatism and crash risk

\begin{tabular}{lll}
\hline Firm & Conservatism & Crash risk \\
\hline Abu Qir Fertilizers \& Chemical Industries Co. & -0.75727 & 0.07062 \\
Commercial International Bank & 0.13935 & 0.00680 \\
Delta Sugar Co. & 0.01911 & 0.00336 \\
Eastern Tobacco Co. & 0.08775 & 0.01921 \\
Oriental Weavers Inc. & 0.17266 & 0.00390 \\
Egypt Iron \& Steel Co. & 0.27872 & 0.02836 \\
Egypt Kuwait Holding & 0.00079 & 0.00638 \\
Al Ezz Dekheila Steel Co. & 0.09632 & 0.02739 \\
Ezz Steel & -0.07265 & 0.05206 \\
Hermes Holding & -0.10103 & 0.01950 \\
Egyptian Media Production City & -0.81141 & 0.01027 \\
Misr Beni-Suef Cement Co. & -0.02166 & 0.00693 \\
Mobinil Co. & 0.12186 & 0.01289 \\
National Bank of Egypt & 0.02565 & 0.02374 \\
National Cement Co. & 0.21039 & 0.00907 \\
Orascom Construction Industries & -0.02069 & 0.00521 \\
Orascom Telecom Media \&Technology Holding & -0.00304 & 0.06947 \\
Misr Cement -Qena & -0.66903 & 0.00609 \\
Qatar National Bank Alahli & 0.00972 & 0.00605 \\
Sinai Cement Co. & -1.3049 & 0.21873 \\
Suez Cement Co. & 0.35629 & 0.01068 \\
Tourah Portland Cement Co. & 0.10138 & 0.00514 \\
\hline
\end{tabular}

Source: authors' analysis

Table 1 presents the descriptive statistics for the major variables discussed in Section 3. It shows the entertained degrees of conservatism in financial reporting and the corresponding potentiality of experiencing crash risk for each firm. The mean value of NCSKEW is 0.028 , suggesting that, on average, $2.8 \%$ of firm-quarter observations experience one or more firm-specific weekly returns that fall within 4.5 standard deviation below the quarter mean. Around $41 \%$ of the sample firms are aggressive concerning their financial information reporting associated with positive skewness values. The value of positive skewness representing the frequency of good news varies directly and increases correspondingly with the increase of degree of aggressive information reporting which refers to the managerial behavior towards the quick disclosure and revealing of good news relative to bad news. On the other 
hand, around 59\% of the sample firms are conservative concerning their financial information reporting associated with lower values of positive skewness referring to the smooth disclosure of bad news relevant to good news. Though conservative firms showed less positive skewness, but as long as this coincides with the relative recognition of bad news versus good news, this sounds beneficial from an economic essence which is far better than presenting large positive skewness that implicitly may have a hindering bad news behavioral element that does not represent the actual transparent financial picture of the firm. Hardly, these findings come with exceptions, but significantly, they recommend the pertinent quest for instant embedding of conservatism in financial reporting as for its information role in demolishing information asymmetry and thus lowering the potentiality for sudden crashes.

Table 2. presents a Pearson correlation $(R)$ matrix for conservatism and crash risk in regression analysis

\begin{tabular}{cc}
\hline \multicolumn{2}{c}{ Regression statistics } \\
\hline $\mathbf{R}$ & 0.67827 \\
R squared & 0.46005 \\
Adjusted R square & 0.43305 \\
Standard Error & 0.03539 \\
\hline
\end{tabular}

\section{Source: authors' analysis}

As shown in table 2, Pearson product-moment correlation coefficient has a value of -0.67827 pointing that the asymmetric-timeliness conservatism measure is significantly and negatively correlated with firm-level crash risk with a 68\% approximately. This means that increasing the delay of news or selectively discloses the good news and intentionally hide bad news from stakeholders is accompanied by an increasing potentiality of experiencing firm-level crash risk which is consistent with our prediction that more conservative firms have lower crash risk. The remaining approximated $32 \%$ represent all other factors and variables that might have the ability to affect firm-level crash risk rather than delayed financial reported news such as firm size, audit committee qualities, the compensation committee, the proportion of the ownership structure, board composition, board meetings, ...etc.

The adjusted R-squared and the coefficient of determination $\left(r^{2}\right)$ are 0.43305 and 0.46005 respectively. So, $46 \%$ of the total variation in firm-level crash risk can be explained by delayed financial reporting (i.e., timeliness of news) denoted in the linear association between the two variables and the other $54 \%$ of the total variation in firm-specific crash likelihood remains unexplained due to the presence of other factors that also affect the probabilities that firms experience crash risk as stated previously. Standard error $(S)$ equals 0.03539 which conveniently indicates that the predicted values are close to the observed values as $S$ had a very small value indicating that the study results could be relied on to be very precise and accurate.

Table 3. ANOVA

\begin{tabular}{ccccc}
\hline Df & SS & MS & F & Significance F \\
\hline
\end{tabular}

\begin{tabular}{cccccc} 
Regression & 1 & 0.02135 & 0.02135 & 17.04061 & 0.00052 \\
Residual & 20 & 0.02506 & 0.00125 & & \\
Total & 21 & & & & \\
\cline { 1 - 2 } & & & & &
\end{tabular}

Source: authors' analysis

Table 4. T - Stat

\begin{tabular}{ccccccc}
\hline & Coefficients & Standard Error & T-Stat & P-value & Lower 95\% & Upper 95\% \\
\hline Intercept & 0.02070 & 0.00776 & 2.66545 & 0.01485 & 0.00450 & 0.03690 \\
X Variable 1 & -0.07775 & 0.01883 & -4.12802 & 0.00052 & -0.11705 & -0.03846 \\
\hline
\end{tabular}

Source: authors' analysis

We used the F-test regression in form of ANOVA test. While R-squared provided an estimate of the strength of the relationship between the model and the response variable, F-test provided a formal hypothesis testing mechanism for this relationship and whether it is statistically significant. From table 3 and table 4, we determined the Significance $F$ which is the $P$-value of $F$ with a value of 0.01485 for the intercept and 0.00052 for the $X$ variable. This is significant since the $R$-squared is approximately 0.46 which is different from zero and the $P$ value is positioned far 
away less than the significance level of 0.05 which placed a strong evidence against the null hypothesis. From the T-stat test, a low P-value suggested that the sample provided enough evidence that you can reject the null hypothesis for the entire population of firms in the Egyptian capital market. The crash risk is regressed on information asymmetry measure of conservatism and the regression output is strongly significant and replicates the underlying theoretic predictions.

The results obtained from this study is significant where the null hypothesis which stated that delayed news has no relation with the potentiality of firm-level crash risk is rejected under all conventional significance levels with a $P$-value of 0.0005 and the alternative hypothesis is accepted and proved to be strongly significant as conservative firms are about $7 \%$ less likely to experience crash risks. So, delaying the disclosure of financial information specially being bad is directly related with the potential occurrence of firm-level crash risk, referring to the informational role of conservatism in financial reporting in mitigating information asymmetry, consequently, lowering the probabilities of experiencing firm-level crash risk.

\section{Conclusions, Limitations, and Directions for Future Research}

The growing information needs of stakeholders who have operational interest in financial information have resulted in the quest for timely and credible financial reports; otherwise, it loses its economic value. Compared to developed countries, companies in developing countries tend to release less information and in a less timely manner as the regulations of most capital markets in developed countries limit the time taken to disclose financial information to ensure that all users of financial information are capable to access them when demanded. In emerging economies, the provision of timely information in corporate reports assumes greater importance since other non-financial statement sources such as media releases, news conferences and financial analysts' forecasts are not well developed and the regulatory bodies are not as effective as in developed countries. Thus, propped to the lack of research on the timeliness of corporate financial statements in emerging economies especially the Egyptian economy, the main objective of this study was the attempt to contribute to the corpus of knowledge regarding the impact of timeliness of financial information reporting (reporting lag) in Egypt which is questioned being below standard represented in information asymmetry phenomenon on firm-level crash risk so as to enhance effective published financial reporting mechanism and uplift the economy to a higher level in the future.

Via analysis, we found that the extent of conservatism, or the timelier recognition of bad news as losses or good news as gains in financial reporting mitigate information asymmetry issues. It is worth to be mentioned that embedding conservatism as a central tenet in effective financial reporting is not only about pointing to the need to timely declare any firm-specific bad news, but also declaring firm-specific good news conditioned on being actually recognized. This is the illustrious essence of conservatism's informational role in mitigating information asymmetry which is consistent with the general notion that conservatism effectively curbs managerial incentives to withhold bad news and/or delay as to the reporting lag regarding its release to outside investors, and thus deters negative information stockpiling, thereby reducing the likelihood to experience stock price crash risk. We found that conservatism, a firm-specific variable, subsumes both information asymmetry and timeliness of news, and explains crash risk with a $68 \%$ explanatory power that is significant under all conventional levels and that the predictive power of conservatism with respect to crash risk is more pronounced for firms with higher information asymmetry. Taken together, we provided strong and robust evidence that conservatism is a reliable indicator of information asymmetry and so forth a predictor of future stock price crash risk with a regression output that is not only statistically significant but also economically significant replicating the underlying theoretic predictions as on average, conservative firms are about $7 \%$ less likely to experience crash risks with a P-value of about 0.0005 .

Nevertheless, the study is not without limitations. The exclusion of companies that do not match the sampling considerations may be a pushing factor from generalization, thus, the study may be extended and modified in a number of ways as it lacks other determinants of timeliness of financial information reporting. Future studies may consider other corporate aspects in Egyptian firms such as the size of the firms, the proportion of the ownership structure, and the board composition. Another dimension that is prone to research is to what extent international firms in Egypt differ from domestic ones as to financial reporting lag and timeliness disclosure of news and how this can affect the firm - level crash exposure.

\section{References}

Anwer S. Ahmed, Scott Duellman. (2011). Evidence on the role of accounting conservatism in montoring managers' investment decisions. Accounting and Finance, 51(3), 609-633. http://dx.doi.org/10.1111/j.1467-629X.2010.00369.x 
Arezoo Haghighat, Banafsheh Farhangzadeh, Mohammad Haghighat. (2015). The impact of institutional ownership on stock price synchronicity and crash risk. Journal of Business and Social Science, 6(4).

Amy P. Hutton, Alan J. Marcus, Hassan Tehranian. (2009). Opaque financial reports, $\mathrm{R}^{2}$, and crash risk. Journal of Financial Economics, 94(1), 67-86. http://dx.doi.org/10.1016/j.jfineco.2008.10.003

Amar Bhide. (1993). The hidden costs of stock market liquidity. Journal of Financial Economics, 34(1), 31-51. http://dx.doi.org/10.1016/0304-405X(93)90039-E

Anwer S. Ahmed, Scott Duellman. (2012). Managerial overconfidence and accounting conservatism. Journal of Accounting Research, 51(1), 1-30. http://dx.doi.org/10.1111/j.1475-679X.2012.00467.x

Alexander Bleck, Xuewen Liu. (2007). Market transparency and the accounting regime. Journal of Accounting Research, 45(2). http://dx.doi.org/10.1111/j.1475-679X.2007.00231.x

Barakat Ahmed, Chenobai Anna, Wahrenburg Mark. (2014). Information Asymmetry around operational risk announcements, 48, 152-179.

Brad M. Barber, Emmanuel T. De George, Reuven Lehavy, Brett Trueman. (2013). The earnings announcement premium around the globe. Journal of Financial Economics, 108(1), 118-138. http://dx.doi.org/10.1016/j.jfineco.2012.10.006

Bruce C. Greenwald, Joseph E. Stiglitz. (1990). Asymmetric information and the new theory of the firm: Financial constraints and risk behavior, working paper no. 3359.

Bok Baik, Jun-Koo Kang, Jin-Mo Kim. (2010). Local institutional investors, information asymmetries and equity returns. Journal of Financial Economics, 97(1), 81-106. http://dx.doi.org/10.1016/j.jfineco.2010.03.006

Christopher S. Armstrong, John E. Core, Wayne R. Guay. (2014). Do independent directors cause improvements in firm transparency? Journal of financial economics, 113(3), 383-403. http://dx.doi.org/10.1016/j.jfineco.2014.05.009

David S. Bates. (2012). U.S. stock market crash risk. Journal of Financial Economics, 105(2), 229-259. http://dx.doi.org/10.1016/j.jfineco.2012.03.004

Daniel Friedman, Ralph Abraham. (2009). Bubbles and crashes: Gradient dynamics in financial markets. Journal of Economic Dynamics and Control, 33(4), 922-937. http://dx.doi.org/10.1016/j.jedc.2008.10.006

Daniel Ferreira, Miguel A. Ferriera, Clara C. Raposo. (2011). Board structure and price informativeness. Journal of Financial Economics, 99(3), 523-545. http://dx.doi.org/10.1016/j.jfineco.2010.10.007

Fan, Yu. (2005). Accounting transparency and the term structure of credit spreads. Journal of Financial Economics, 75, 53-84. http://dx.doi.org/10.1016/j.jfineco.2004.07.002

Gary C. Biddle, Gilles Hilary, Rodrigo S. Verdi. (2009). How does financial reporting relate to investment efficiency? Journal of Accounting and Economics, 48(2-3), 112-131. http://dx.doi.org/10.1016/j.jacceco.2009.09.001

Hamdan A. M. Mousa, Abzakh M. Hasan, Al-Ataibi M. Hosni. (2011). Factors influencing the level of accounting conservatism in the financial statements, 4(3).

Hayne E. Leland, David H. Pyle. (1977). Information asymmetries, financial structure, and financial intermediation. the journal of finance, 32(2).

Hendrik Bessembinder, William Maxwell, Kumar Venkataraman. (2006). Market transparency, liquidity externalities, and institutional trading costs in corporate bonds. Journal of Financial Economics, 82(2), 251-288. http://dx.doi.org/10.1016/j.jfineco.2005.10.002

Hojo Jo, Yongtae Kim. (2007). Disclosure frequency and earnings management. Journal of Financial Economics, 84(2), 561-590. http://dx.doi.org/10.1016/j.jfineco.2006.03.007

Heng An, Ting Zhang. (2013). Stock price Synchronicity, crash risk, and institutional investors. Journal of Corporate Finance, 21, 1-15. http://dx.doi.org/10.1016/j.jcorpfin.2013.01.001

Jacob Boudoukh, Ronen Feldman, Shimon Kogan, Matthew P. Richardson. (2013). Which news moves stock prices? A textual analysis, National Bureau of Economic Research (NBER), Working paper no. 18725.

Joseph Chen, Harrison Hong, Jeremy C. Stein. (2001). Forecasting Crashes: trading volume, past returns, and conditional skewness un stock prices. Journal of Financial Economics, 61(3), 345-381. http://dx.doi.org/10.1016/S0304-405X(01)00066-6 
James Hueng, James B. Mcdonald. (2005). Forecasting asymmetries in aggregate stock market returns: Evidence from conditional skewness. Journal of Empirical Finance, 12(5), 666-685. http://dx.doi.org/10.1016/j.jempfin.2005.01.001

Joel F. Houston, Baruch Lev, Jenny Wu Tucker. (2010). To guide or not to guide? Causes and consequences of stopping quarterly earning guidance. Contemporary Accounting Research, 27.

Jeong-Bon Kim, Yinghua Li, Liandong Zhang. (2011). Corporate tax avoidance and stock price crash risk: firm level analysis. Journal of Financial Economics, 100(3), 639-662. http://dx.doi.org/10.1016/j.jfineco.2010.07.007

Jeremy C. Stein, Harrison Hong (2003) Differences of opinion, short sales constraints, and market crashes. Review of Financial Studies, 16(2), 487-525. http://dx.doi.org/10.1093/rfs/hhg006

Jeffrey L. Callen, Xiaohua Fang. (2011). Institutional investors and crash risk: Monitoring or Expropriation?, Working paper no. 1804697.

J. Richard Dietrich, Karl A. Muller, Edward J. Reidl. (2012). Asymmetric timeliness of accounting conservatism, Review of Accounting Studies, Working paper no. 77.

Jeong_Bon Kim, Zheng Wang, Liandong Zhang. (2014). CEO overconfidence and stock price crash risk, Contemporary Accounting Research.

Kathleen W. Hanley, Gerard Hoberg. (2012). Litigation risk, strategic disclosure, and the under-pricing of the initial public offerings. Journal of Financial Economics, 103(2), 235-254. http://dx.doi.org/10.1016/j.jfineco.2011.09.006

Kalok Chan, Allaudeen Hameed. (2006). Stock price synchronicity and analyst coverage in emerging markets. Journal of Financial Economics, 80(1), 115-147. http://dx.doi.org/10.1016/j.jfineco.2005.03.010

Li Jin, Stewart C. Myers. (2006). R2 around the world: New theory and new tests. Journal of Financial Economics, 79(2), 257-292. http://dx.doi.org/10.1016/j.jfineco.2004.11.003

Mikhail Pevzner, Fei Xie, Xiangang Xin. (2015). When firms talk, do investors listen? The role of trust in stock market reactions to corporate earnings announcements. Journal of Financial Economics, 117(1), 190-223. http://dx.doi.org/10.1016/j.jfineco.2013.08.004

Mahdi M. Zadehfard, Mohsen Lotfi, Mohammad R. Fathi. (2011). The effect of conservative accounting on reducing the stock price crash risk ( case Study: Companies listed in Tehran stock exchange Middle-East). Journal of Scientific Research, 10(6), 743-748.

Mark L. Defond, Mingyi Hung, Robert Trezevant. (2007). Investor protection and the information content of annual earnings announcement: International evidence. Journal of Accounting and Economics, 43(1), 37-67. http://dx.doi.org/10.1016/j.jacceco.2006.09.001

Nianhang Xu, Xiaorong Li, Qingbo Yuan, Kam C. Chan. (2014). Excess perks and stock price crash risk: Evidence from China. Journal of Corporate Finance, 25, 419-434. http://dx.doi.org/10.1016/j.jcorpfin.2014.01.006

Pervin K. Shroff, Ramgopal Venkataraman, Suning Zhang. (2013). The conservatism principle and the asymmetric timeliness of earnings: An event-based approach. Contemporary Accounting Research, 30(1), 215-241. http://dx.doi.org/10.1111/j.1911-3846.2011.01151.x

Paul Brockman, Ivonne Liebenberg, Maria Schutte. (2010). Co-movement, information production, and the business cycle. Journal of Financial Economics, 97(1), 107-129. http://dx.doi.org/10.1016/j.jfineco.2010.03.008

Pornanong Budsaratragoon, David Hillier, Suntharee Lhaopadchanc. (2013). Does corporate governance improves transparency in emerging markets? Journal of Financial Management, Markets, and Institutions, 2(1), 87-104.

Randall Morck, Bernard Yeung, Wayne Yu. (2000). The information content of stock markets: Why do emerging markets have synchronous stock price movements? Journal of Financial Economics, 58(1-2), 215-260. http://dx.doi.org/10.1016/S0304-405X(00)00071-4

Ray Ball, Lakshmanan Shivakumar. (2005). Earnings quality in UK private firms: Comparative loss recognition timeliness. Journal of Accounting and Economics, 39(1), 83-128. http://dx.doi.org/10.1016/j.jacceco.2004.04.001

Ray Ball, S. P. Kothari, Valeri V. Nikolaev. (2013). Econometrics of the Basu asymmetric timeliness coefficient and accounting conservatism. Journal of Accounting Research, 51, 1071-1097. http://dx.doi.org/10.1111/1475-679X.12026 
Ryan Lafond, Sugata Roychowdhury. (2008). Managerial ownership and accounting conservatism. Journal of Accounting Research, 46(1), 101-135. http://dx.doi.org/10.1111/j.1475-679X.2008.00268.x

Ryan Lafond, Ross L. Watts. (2008). The informational role of conservatism. The Accounting Review, 83(2), 447-478. http://dx.doi.org/10.2308/accr.2008.83.2.447

Ross L. Watts. (2002). Conservatism in Accounting. Working paper no. FR 02-21.

Shaiban, M. (2011). Reporting Timeliness, Private Information and Stock Price Synchronicity Morck et al. (2000) Revisited. Capital markets, Market Efficiency e -Journal, 3(91).

Sonali Hazarika, Jonathan M. Karpoff, Rajarishi Nahata. (2012). Internal corporate governance, CEO turnover, and earnings. Journal of Financial Economics, 104(1), 44-69. http://dx.doi.org/10.1016/j.jfineco.2011.10.011

Siu Kai Choy, Ying Zheng. (2011). Disclosure environment and earnings announcement premia: international evidence and further U.S. evidence, SSRN electronic journal. http://dx.doi.org/10.2139/ssrn.1781933

Sophia J. W. Hamm, Edward X. Li, Jeffrey Ng. (2014). Management earnings guidance and stock price crash risk, Research paper no. 10.

Sudipto Dasgupta, Jie Gan, Ning Gao. (2010). Transparency, price informativeness, and stock return synchronicity: Theory and evidence. Journal of Financial and Quantitative Analysis, 45(5), 1189-1220. http://dx.doi.org/10.1017/S0022109010000505

Sudha Krishnaswami, Venkat Subramaniam. (1999). Information asymmetry, valuation, and the corporate spin-off decision. Journal of Financial Economics, 53(1), 73-112. http://dx.doi.org/10.1016/S0304-405X(99)00017-3

Sylwia Nowak, Heather M. Anderson. (2014). How does public information affect the frequency of trading in airline stocks? Journal of Banking and Finance, 44, 26-38. http://dx.doi.org/10.1016/j.jbankfin.2014.03.033

Studipta Basu. (1997). The conservatism principle and the asymmetric timeliness of earnings. Journal of Accounting and Economics, 24(1), 3-37. http://dx.doi.org/10.1016/S0165-4101(97)00014-1

S. P. Kothari, Jonathan Lewellen, Jerold B. Warner. (2006). Stock returns, aggregate earnings surprises, and behavioral finance. Journal of Financial Economics, 79(3), 537-568. http://dx.doi.org/10.1016/j.jfineco.2004.06.016

Stephen H. Penman, Xiao-Jun Zhang. (2002). Accounting conservatism, the quality of earnings, and stock returns. The Accounting review, 77(2), 237-264. http://dx.doi.org/10.2308/accr.2002.77.2.237

Sugata Roychowdhury, Ross L. Watts. (2007). Conference issue on corporate governance: financial reporting, internal control, and auditing asymmetric timeliness of earnings, market-to-book conservatism in financial reporting. Journal of Accounting and Economics, 44(1-2), 2-31. http://dx.doi.org/10.1016/j.jacceco.2006.12.003

S. P. Kothari, Susan Shu, Peter D. Wysocki. (2009). Do managers withhold bad news? Journal of Accounting Research, 47(1), 241-276. http://dx.doi.org/10.1111/j.1475-679X.2008.00318.x

Sudha Krishnaswami, Venkat Subramaniam. (1999). Information asymmetry, valuation, and the corporate spin-off decision. journal of financial economics, 53, 73-112. http://dx.doi.org/10.1016/S0304-405X(99)00017-3

Tony T. Tang. (2009). Information asymmetry and firms' credit market access: Evidence from Moody's credit rating format refinement. Journal of Financial Economics, 93(2), 325-351. http://dx.doi.org/10.1016/j.jfineco.2008.07.007

Warren Bailey, G. Andrew Karolyi, Carolina Salva. (2006). The economic consequences of increased disclosure: Evidence from international cross-listings. Journal of Financial Economics, 81(1), 175-213. http://dx.doi.org/10.1016/j.jfineco.2005.06.002

Wayne Guay, Robert Verrecchia. (2006). Conference issue on the implications of changing financial reporting standards: Discussion of an economic framework for conservative accounting and Bushman and Piotroski (2006). Journal of Accounting and Economics, 42(1-2), 149-165. http://dx.doi.org/10.1016/j.jacceco.2006.03.003

Yongtae Kim, Haidan Li, Siqi Li. (2014). Corporate social responsibility and stock price crash risk. Journal of Banking and Finance, 43, 1-13. http://dx.doi.org/10.1016/j.jbankfin.2014.02.013

Zhe An, Donghui Li, Jin Yu. (2015). Firm crash risk, information environment, and speed of leverage adjustment. Journal of Corporate Finance, 31, 132-151. http://dx.doi.org/10.1016/j.jcorpfin.2015.01.015 